\title{
Asian Financial Crisis: An Analysis of the Contagion and Volatility Effects in the Case of Malaysia
}

\author{
Mori Kogid (Corresponding author) \\ School of Business and Economics, Universiti Malaysia Sabah \\ 88999 Kota Kinabalu, Sabah, Malaysia \\ Tel: 60-88-320-000 Ext: $1627 \quad$ E-mail: morikogid@gmail.com \\ Kok Sook Ching \\ School of Business and Economics, Universiti Malaysia Sabah \\ 88999 Kota Kinabalu, Sabah, Malaysia \\ Tel: 60-88-320-000 Ext: 1642 E-mail: emily@ums.edu.my
}

Mansor Jusoh

School of Economics, Faculty of Economics and Business, Universiti Kebangsaan Malaysia

43600 Bangi, Selangor, Malaysia

E-mail: mansorj@pkrisc.cc.ukm.my

\begin{abstract}
The emergence of the Asian financial crisis in July 1997 had a tremendous impact on the economies of the Asian countries. This study aims at linking the contagion theory and the crisis faced in Malaysia with more emphasis on the effect of the contagion volatility in the currency exchange market. This research uses the co-relation analysis, models of ARCH, GARCH and also GJR-GARCH in demonstrating the link. The results show that the crisis in Malaysia was not merely due to the weakness in its economic fundamentals, but also due to the contagion and volatility effects particularly originated from Thailand and Singapore. This study suggests the need for a more systematic management system with improved transparency in the financial sector even though the effect of the crisis contagion could hardly be prevented.
\end{abstract}

Keywords: Currency exchange rate, Contagious volatility spillover, GARCH, GJR-GARCH

\section{Introduction}

Malaysian Ringgit was devaluated as a result of the emergence of the financial crisis in the mid-1997. The Malaysian economic scenario was devastated and changed drastically ever since the Thai government decided to float its currency, the Baht on 2nd July 1997. Six months prior to the crisis, Malaysia's macroeconomic pointers did not show any sign that this country would be easily affected by such a crisis as in Thailand even though there was concern about the country's fast developmental growth (Ishak, 2000). The economic growth achieved was seemingly too high and continuous, exceeding the country's own potential rate and the problem of resource imbalance between funds and investments was apparent.

Nonetheless, Malaysia's economic growth had showed a declining sign since early 1996 whereby the growth rate declined slightly from about 9.4 per cent in 1995 to about 8.6 per cent in 1996. Meanwhile, the national current account deficit payment balance declined from about 10.4 per cent in 1995 to about 5.1 per cent in 1996. The government's financial placing was also strong recording a surplus for five years continuously before the crisis.

Apart from these, the inflation and unemployment rates were recorded low at about 2.6 per cent and about 2.7 per cent respectively in 1996. Foreign funding were sufficient to fund for the country's imports for four months and there were surpluses in the short term dues which were borne by the people of Malaysia. Steps in early paybacks of foreign loans 
caused Malaysia to record a lower level of foreign loans which was only about 32.7 per cent of its KDNK in 1997 with total foreign loans amounting USD3.3 billion or about 14.4 per cent of its total loans (Ishak, 2000).

The devaluation of Ringgit was apparent between July 1997 and early 1998. On 13th January 1997, Ringgit achieved its highest level at RM2.46 per USD1. This position did not last and instead became worse. The value of Ringgit started to decline in the mid of July 1997. The value of the currency fell to its lowest at RM4.80 per USD1 in January 1998. On 10th February 1998, Ringgit managed to achieve a satisfactory level of RM3.55 per USD1 and was maintained at a range of RM3.60 to RM3.70 per USD1.

The decline of the Malaysian Ringgit during this period was the most devastating in its history. The economic slump which fell upon the country since July 1997 was different to what had happened in the mid-1980s, of which the value of Malaysian Ringgit was not much affected. During the crisis in 1997, the long fall of the Malaysian Ringgit resulted in damages to all sectors and slowed the country's economic growth.

It must be agreed that because of globalization, Malaysia would be affected by global events outside of the country. There were horrendous implications to the entire Thai economic system following the fall of the Baht currency. The fall of Baht simultaneously played a role in the outbreak of another crisis which eventually erupted in other East Asian countries and this situation is said to be the early bandwagon effect where the impact on Thailand also resulted in implications to its neighboring countries.

The devaluation of Baht on 2nd July 1997 became the start of the financial crisis that spread over to other East Asian countries particularly South Korea, Indonesia, Philippines, Malaysia and Japan. Even those countries which were thought to be able to withstand the crisis such as Hong Kong, Singapore, and Brunei were dragged into this critical scenario. Actually, Thailand had been facing currency speculation threats since June 1996. On 14th May 1997, it was reported that the trading of Baht had reached USD10 billion (Md. Nasrudin, 2000). Therefore, it would be difficult for the finance authority of Thailand, a country with a small economy and moderate economic growth to face the international speculative activities of which resulted in large capital outflows.

Meanwhile, in Indonesia, the financial crisis affected its trading, foreign investments, and lending the most. Following the contagion, the value of the Indonesian Rupiah declined badly relative to the currencies of other South East Asian countries. Rupiah was depreciated to as low as IDR17 000 compared to USD1. Even more alarming, the value of Rupiah decreased by about 85 per cent in June 1997 and one third of the Indonesia's private sector debt amounting USD80 billion was borrowed from the financial intuitions in Japan (Md. Nasrudin, 2000).

Following the crisis, Bank Negara Malaysia (BNM) intervened aggressively to protect the value of the Malaysian Ringgit. On 14th July 1997, BNM stopped protecting the value of Ringgit and eventually, the value of Ringgit experienced a decline on 24th July 1997. Meanwhile, the Indonesian Rupiah started to receive tremendous pressure from currency speculators on 13th August 1997. This was followed by South Korea stopping to protect its currency, the Won, on 17th November 1997 and finally on 3rd December 1997, Baht, Rupiah, Ringgit and Won experienced their lowest falls.

In short, the falls of the South East Asian currencies affected each other due to their interdependency in various aspects. The falls began with the value of Baht declining on 2nd July 1997, followed by Peso on 11th July 1997, Ringgit on 14th July 1997, Rupiah on 21st July 1997, and the Singapore Dollar fell in stages which began on 24th July 1997. The crisis then spread to South Korea with the Won's value declined on 23rd October 1997 (Md. Nasrudin, 2000).

According to Peng Yie (2000), the outbreak of the East Asian financial crisis could probably be avoided if Thailand floated its exchange rate six months before the crisis occurred. This is because, if Thailand had practiced an organized floating exchange rate regime, and did not exhaust all its reserves amounting USD32 billion to protect the value of Baht, Thailand could have stopped this contagion to other East Asian countries, even though it might not able to stop the economic bubble to burst. This seems true in the view of Dornbusch (in Ugarteche, 2000), who stated the following:

Don't fight to hang on to an exchange rate, let it float. The more you struggle, the worse the crisis and more reserves will erode. Better to let it float before the disaster to avoid the steep fall and the cost in lost reserves that would have to be paid if it postponed.

The financial crisis hit Thailand and as a result, the crisis spread to the neighboring countries in weeks. Indonesia, Malaysia, and Philippines for examples felt the effect of the blow directly, while Singapore, Hong Kong, and Taiwan were affected at a smaller and limited scale.

The analysis of this research is presented in six parts. Part 2 elaborates the crisis and the contagion theory, and also discusses the contagion concept which was presented by Rigobon (1999). Part 3 explains about data and study set. Part 4 is a closer examination of the theory and the model specification used in this research. The empirical analysis and results are discussed in part 5 and part 6 concludes. 


\section{Crisis and Contagion Theory}

Contagion is a phenomenon when a currency crisis falls on a country which then triggers another crisis to occur in other countries where these countries show a chain of weak economies. The contagion theory shows that there is no country in the region which can parry the effect of contagion of such an economical crisis and the besetting currency problems.

According to the Oxford Dictionary, the term "contagion" is defined as an infectious disease transmission through contact. The word contagion is taken from the Latin language namely con meaning 'with' and tangere which means 'touch'. However, the definition of contagion is really still vague.

In his research, Rigobon (1999) defined contagion through three classifications as following:

(i) Contagion can be interpreted as one crisis agreed upon that is when devastation occurs in a country, it would then create a speculative attack to another country;

(ii) Based on fact, the countries experiencing a crisis will experience volatility increase in their returns. So, contagion can be characterized as transmission of volatility between one country with another country; and

(iii) Contagion can also be defined as the change in shock that spread among affected countries.

However, definitions (i) and (ii) only exist in specific cases and definition (iii) does not exist in data or reality. In another case, contagion may be more visible when a crisis occurs, but may still exist at any time when there is no occurrence of a crisis.

\section{Data and Study Set}

The Exchange Rate data $\left(\mathrm{ER}_{\mathrm{t}}\right)$ for the ASEAN countries including Malaysia, Indonesia, Philippines, Singapore, Thailand and also South Korea is acquired from the International Financial Statistics Monthly and IMF Yearbook. The data series used were monthly data beginning from July 1997 to August 2000. The Econometric Views program is used to produce all estimations and calculations in this study.

The study set begins with measuring the degree of the spread of the crisis based on a correlation analysis. An exchange rate variable is taken into account in seeing a correlation relationship that exists between the Malaysian currency market and the market of other countries' currencies.

The presence of volatility in the currency market is also analyzed using the GARCH (Generalized ARCH), and the GJR-GARCH (Glosten, Jagannathan \& Runkle, 1993) models to further explain the role of volatility in the currency market as each of these would have a different role in reflecting volatility that exists in currency market.

Engle (1982) was the first to introduce the ARCH model, while the GARCH model was introduced by Bollerslev (1986) for the purpose of representing the ARCH process with the higher level (q). According to Bollerslev, the GARCH model is more appropriate and parsimony when faces with the higher level of ARCH model. Akgiray (1989) had looked into the trait effect of heteroscedasticity to stock return. Based on the ARCH and GARCH models that took into account the heteroscedasticity factor, he proved that these models are capable of predicting volatility better as compared to other models. The GJR GARCH model on the other hand was introduced by Glosten et al. in 1993. This model tries to take into account the asymmetric shock effect towards volatility in the financial market's return.

\section{Theory and Model Specification}

The study set explains how the testing procedure is made and in particular, the models are specified according to the stated testing procedure in greater detail. The model categories are classified into two testing forms which are: test based on correlation analysis, and volatility of the financial market. For each category mentioned, a model is formed to facilitate ease of testing to determine the degree or magnitude of the contagion spread, volatility and contagion presence among affected financial markets.

\subsection{Correlation}

Baig and Goldfajn (1999) conducted a study on the presence of the contagion in the financial markets of Thailand, Malaysia, Indonesia, Korea and Philippines. Based on the outcome of the study, they found that there existed a significant correlation relationship in currencies and it was increasing throughout the crisis period. They carried out the tests on two period namely prior (tranquil) and during the crisis.

The results of their study showed that contagion did exist in the foreign debt market; however its existence in the stock market was more obvious. Contagion in the foreign debt market gave control pressure to the presence in elements of panic within the financial system which eventually brought about the emergence of the Asian financial crisis. Their research findings supported most opinions which reflecting a panic crisis within the financial system as one of the causes as to how the spreading of the crisis happened to most countries in the Asian region.

Kawai, Newfarmer and Schmukler (2001) studied three different crisis categories namely the economic crisis that started in Mexico (1994), Thailand (1997) and Russia (1998). According to them, the economic shock which started in 
the countries mentioned above had a positive effect to their neighboring countries, isolated countries and also new and developing markets. They regarded the transmission and crisis shock that happened between one country and another as an 'infection'. They also focused their study on the Asian financial crisis and the contagion that occurred, and studied the various channels which might have caused the contagion in the affected countries.

The outcomes of their study concluded that there were some dominant channels showing how the 'virus' which was said to stem from Thailand spread to other countries as a result of mutual association and reactions which existed among financial variables such as exchange rate, interest rates and stock market prices. At first glance, the study indicated that the strong correlation between trade and foreign direct investment (FDI) was a dominant channel to the presence of a contagion. The study revealed that there were strong ties between trade and FDI among East Asian countries, while Korea had a weak correlation in trade or FDI with Thailand.

The second channel was that the demand and supply effects through the real sector required a longer period as compared to the actual time of occurrence and the third explained that there existed speculative activities by various speculators towards affected countries with minimal trade or FDI ties.

At the same time, a contagion crisis did exist in the financial sector through the ties which were present in the financial system linking the affected countries. As to maintain the quality of portfolio, those banks facilitating international trade would have taken measures to prevent the impact of any financial shock in a country to spread to other neighboring countries or to the country's trade partners. Nonetheless, the presence of the international trade facilitation seemed worsen the spread and exposed the crisis to other countries. This view is backed by Kaminsky and Reinhart (2000).

Meanwhile, there is a very high possibility that the contagion was encouraged by the perception and sentiment of investors themselves. Two obvious states reflected this situation namely the normal or natural reaction from investors onto problems that they faced, and the second is that the fear or worry that are usually felt by investors pushed them to make decisions in a hurry or to act irrationally (immediately) without taking into account the decisions made by other investors. Such a situation would in the end encourage panic to occur among investors and make the market act inefficiently.

In the study on the effect of the crisis spread, which started in Mexico in 1994 towards East Asian countries and Latin America, Frankel and Schmukler (1998) discovered that there was a less shock impact to East Asian countries as compared to Latin America. This shock had a positive effect directly onto Latin America which reflected a powerful implication onto countries with a weak and fragile fundamental foundation such as the Philippines which had a high export debt ratio. There are others who suggest that the financial crisis in Southeast Asia was not due to the direct impact of the crisis that happened in Korea. This view assumed that the collapse in the Taiwan's economy played an important role in causing the crisis to Korea and was the initial effect onto the ASEAN-4 countries through financial institutions.

\subsection{Volatility}

The most popular models for conditional variance include ARCH, GARCH and GJR-GARCH. All of these three models are capable in predicting return volatility in the financial market and may create an impact onto investors' portfolio decision (Engle, 1993). The volatility of the financial market can be predicted and such an observation can provide significant implications for portfolio management and asset's price positioning strategy. Most investors observe ways to avoid risk, for example they may choose to make adjustments to their portfolio by reducing their commitments on assets which are predicted to increase in volatility or they may use diverse dynamic approaches to their portfolio to protect themselves from predicted increase in volatility.

Usually, the equation which is used to reflect the relationship in exchange rate variable among the Malaysian market and markets of other countries is in the form of returns as follows:

Exchange Rate Return $\left(S_{i, t}\right)$ :

$$
S_{i, t}=\log \left(E R_{i, t} / E R_{i, t-1}\right) * 100
$$

where $E R_{i, t}$ is exchange rate to the country $i$ over the American Dollar (USD) in the period $t$. Exchange rate return to each country is calculated as the difference in percentage in the exchange rate in the logarithmic form.

In short, the basis to the formation of the ARCH (p) model introduced by Engle (1982) is as follows:

$$
y_{t}=c+x_{t}^{\prime} \xi+\varepsilon_{t} \quad \text { (Mean Equation) }
$$

where $\mathrm{t}=1, \ldots, \mathrm{T}$

$\varepsilon_{t} \mid \psi_{t} \sim N\left(0, h_{t}\right)$ 


$$
h_{t}=\alpha_{0}+\sum_{i=1}^{p} \alpha_{i} \varepsilon_{t-i}^{2} \quad \text { (Variance Equation) }
$$

where $y_{t}$ is a dependent variable and $h_{t}$ is a conditional variance $\left(h_{t}=\sigma_{t}^{2}\right)$ and $\psi_{t_{1}}$ is a variable set or information which can be acquired at $t$ time period where $\psi_{t}=\left(y_{t-1}, x_{t-1}, y_{t-2}, x_{t-2}, \ldots\right)$ whereas $x_{t}$ is kx1 external variable vector which can also take the lag value of the dependent variable itself which is $y_{t-1}$ and $\xi$ is kx1 parameter vector for the external variable used. The coefficients, $\alpha_{0}$, and $\alpha_{1}$ have to be positive to ensure a positive variance. The coefficient $\alpha_{1}$ must less than 1 otherwise $h_{t}$ will continue to increase over time, eventually exploding.

The GARCH model was introduced by Bollerslev (1986) for the purpose of representing the ARCH process which has stage (q), the higher level. The GARCH model is more appropriate and parsimony when compared with the higher class ARCH model. The conditional variance equation specified in (5) is a function of three terms namely a constant term, news about volatility from the previous period, measured as the lag of the squared residual from the mean equation, and the last period's forecast variance. All coefficients $\alpha_{i}$ and $\beta_{i}$ must be positive and the coefficients $\alpha_{1}$ and $\beta_{1}$ must less than 1 that is $\alpha_{1}+\beta_{1}<1$ for stationary; if $\alpha_{1}+\beta_{1} \geq 1$, we have a so-called "integrated GARCH" process or IGARCH (Hill, Griffiths \& Lim, 2008). In addition, if the sum of the coefficients $\alpha_{1}+\beta_{1}$ is very close to one, indicating that volatility shocks are quite persistent. The model for GARCH $(p, q)$ created is presented as follows:

$$
y_{t}=c+x_{t}^{\prime} \xi+\varepsilon_{t}
$$

where $\mathrm{t}=1, \ldots, \mathrm{T}$

$\varepsilon_{t} \mid \psi_{t} \sim N\left(0, h_{t}\right)$

$$
h_{t}=\alpha_{0}+\sum_{i=1}^{p} \alpha_{i} \varepsilon_{t-i}^{2}+\sum_{i=1}^{q} \beta_{i} h_{t-i}
$$

Meanwhile, the GJR GARCH $(1,1)$ model was introduced by Glosten et al. (1993) whereby this model tries to take into account the asymmetrical shock effect onto return volatility. The GJR GARCH model created is presented as follows:

$$
h_{t}=\alpha_{0}+\alpha_{1} \varepsilon_{t-1}^{2}+\beta h_{t-1}+\gamma D_{t-1}^{-} \varepsilon_{t-1}^{2}
$$

This model only shows the equation variance because there are no changes in the mean equation. This model includes a dummy variable namely $D_{t-1}^{-}$which will take value 1 if $\varepsilon_{t-1}<0$ and 0 for others. This would cause the equation to have a different gradient when the value $\varepsilon_{t-1}$ has a different sign. As compared to other previous models which do not take into account the $\operatorname{sign} \varepsilon_{t-1}$, this model is more suitable in order to see the asymmetrical shock effect towards volatility in returns. There are a priori reasons to suspect that the coefficient $\gamma$ as well as $\alpha_{1}+\gamma$ are negative, since empirical evidence suggests that a positive innovation to return is associated with a decrease in return volatility. However, if $\alpha_{1}+\gamma$ is negative, the conditional variance can potentially become negative for some realization of $\varepsilon_{t}$ (Glosten et al., 1993). Note that the threshold GARCH (TGARCH) model of Zakoian (1994) is very similar to GJR-GARCH but models the conditional standard deviation instead of the conditional variance.

Meanwhile, the forming of contagion volatility model based on the GARCH $(1,1)$ model on the Malaysian financial market was modified from Wee Beng, Lee Ying \& Chee Chee (1999) and is presented as follows:

$$
\Delta y_{t}=\rho_{0}+\rho_{1} \Delta y_{t-1}+\rho_{2} \Delta y_{t-1}^{q}+\varepsilon_{t}
$$

$\varepsilon_{t} \mid \psi_{t} \sim N\left(0, h_{t}\right)$

$$
h_{t}=\alpha_{0}+\alpha_{1} \varepsilon_{t-1}^{2}+\beta_{1} h_{t-1}+\gamma_{1} V_{t}^{2 q}+\gamma_{2} V_{t-1}^{2 q}
$$

where:

$y \quad=$ Ringgit exchange rate return

$y^{q}=$ exchange rate return where

$$
q=\text { Thailand (T), Indonesia (I), Philippines (P), Singapore (S) and Korea (K). }
$$


$V^{2 q}=$ variance on shock in nation $\mathrm{q}$ after allowing change effect in five other countries.

For example, the shock variance on the Baht exchange rate return, $V^{2 T}$ where a square error is attained from the following regressed equation:

$$
\Delta y_{t}^{T}=\alpha_{0}+\sum_{i=1}^{n} \beta_{i} \Delta y_{t-i}^{T}+\sum_{i=0}^{m} \delta_{i} \Delta y_{t-i}^{K}+\sum_{i=0}^{m} \phi_{i} \Delta y_{t-i}^{I}+\sum_{i=0}^{m} \gamma_{i} \Delta y_{t-i}^{P}+\sum_{i=0}^{m} \psi_{i} \Delta y_{t-i}^{S}+\sum_{i=0}^{m} \theta_{i} \Delta y_{t-i}^{M}
$$

Wee Beng et al. (1999) used the GARCH $(1,1)$ model in their study of currency volatility contagion in other countries like Korea, Indonesia and Thailand on Malaysian Ringgit. Through this, it was found that the conditional volatility on Malaysian Ringgit received a bigger blow especially the impact of the volatility shock on the Thai Baht compared Korea's Won and Indonesian Rupiah.

Koutmos and Saidi (2001) conducted a study on the positive bilateral trade ties in the capital market for new market countries namely Hong Kong, Malaysia, Philippines, Singapore, Taiwan and Thailand by using daily data for share price index from 2nd January 1990 to 9th September 1996. The study assumed that there were two kinds of trades which were maximization of risk dodger utility, and positive bilateral trade. The study found that the bilateral trade is an important factor in determining short-term movements in stock return. During the high volatility period, investors or traders strive to influence share prices. The outcomes of the study also showed that the bilateral trade is asymmetric when the market is rising or declining. However, trade seems more active when the market is declining and negative shock would have a larger effect on the volatility in stock return as compared to the positive shock. Such a reaction is also consistent with the 'leverage effect' which is more related to the bilateral trade when the market is on the decline.

Meanwhile, Dungey and Martin (2000) studied and measured the degree of contagion in the East Asian countries during the financial crisis. The result of their study showed that the contagion effect on the movement of exchange rate was identified as a result of unanticipated shock from one country to another country after taking into consideration the hidden factors (latent) as ordinary shock that existed and of a global form, and also specific shock originating the country itself. Based on the measurement made onto the level of contagion which began in Thailand, they estimated that there was almost 55 per cent of exchange rate volatility in Indonesia, and less than 3 per cent in Malaysia and South Korea. They concluded that the effect of the contagion crisis did exist starting from Thailand and moved to Malaysia and the contagion effect to Indonesia spread too fast.

\section{Analysis and Empirical Decision}

The theoretical link of the financial crisis chronology that occurred in the Asian region in July 1997 has been highlighted previously. How such a crisis which started in Thailand could occur and spread to other countries in such a short period? In merely a few weeks, most economies of the Asian and South East Asian countries fell and a rather obvious destruction was experienced.

In this context, Malaysia was dragged into a dilemma when the unanticipated crisis also beset on this country. Subsequently, various opinions did arise in describing the problems which more or less answered some of the questions as to why and how Malaysia was also trapped in this difficult crisis.

Some are with the opinion that the crisis that happened in Malaysia originated from its weak basic economic fundamental and there are also views that due to globalization, Malaysia is mutually linked with other countries in many ways especially in terms of the financial market. Malaysia is said to have received the same amount of impact of this contagion crisis as other affected countries especially its neighboring countries because Malaysia is located in the same region with most of the countries hit by the crisis. Therefore, in this chapter, the analysis on empirical decision will more or less address Malaysia's issues and the contagion volatility in the financial market.

\subsection{Summary Statistics and Correlation Analysis}

The analysis starts with an estimate of the important statistics, the exchange rate (ER) of a number of six countries including Malaysia to identify the status of the market positioning for each country. This is shown in Table 1 in appendix whereby on average, the exchange rate for each country is 1521.80 to the American Dollar (USD), by which Indonesia is the country which influenced the exchange rate the highest at 7833.34 , followed by Korea at 1213.37 , Philippines at 39.55, then Thailand, Malaysia and Singapore at 39.12, 3.76 and 1.67 respectively.

The exchange rate value for Indonesia was 2599 to 14900, for Korea, the rate was 892 to 1695 and 32.07 to 54.92 for Thailand. The exchange rate volatility risk to each country was fairly low whereby the standard deviation was at the rate of 0.07 to 3.69, except for Indonesia and Korea of which it is recorded at the rate of 2532.38 and 173.51 respectively. Overall, Indonesia and Korea faced the highest instability risk in the exchange rate. The normalization test also indicates that the exchange rates in these countries were abnormally distributed except Indonesia and Korea. This is 
shown by the value of skewness, kurtosis and Jarque-Bera's statistics which pushed the exchange rate distribution normalization for countries like Malaysia, Philippines, Thailand and Singapore.

Based on the monthly data from July 1997 to August 2000, the correlation analysis shows that the correlation degree in the exchange rate between Malaysia and other countries was fairly high as shown in Table 2 which was 0.622 to 0.845 . Malaysia and other countries like Indonesia, Singapore and Philippines had the highest correlation degree compared to Thailand and Korea. This same circumstance also shows that the effect of change in the currency value or exchange rate for the countries mentioned also affected Malaysia's financial market. This also gives the picture that Malaysia's economy during the crisis was easily exposed to external shocks and can be hit by a crisis through contagion.

The correlation analysis onto the financial market of the countries mentioned shows that overall Malaysia's market had a high correlation degree with all the countries mentioned. The occurrence of the crisis in Malaysia was not merely due to the own national economy weakness, but was also caused by the impact from other correlated countries especially through the links in the financial market. It cannot be denied that trade and finance policy implementation were too independent causing these countries to be easily become fragile not only to internal shock but also to external shock. Elimination is one of the important features in the Bretton Woods's system whereby capital control may also be another reason to the occurrence of the Asian financial crisis in 1997. A misunderstanding of the financial liberalization policy experience without orderly control and supervision was also another basis for the crisis to occur.

\subsection{Volatility Analysis}

Table 3 reflects the volatility exchange rate return for each of the countries in this study. Almost all countries indicate that volatility did exist (ARCH's impact) in exchange rate return as shown by the coefficients, $\alpha_{1}$ which is significant, except in the case of Philippines and Singapore. Indeed, all countries have experienced with GARCH's impact as shown by the coefficient, $\beta_{1}$.

The estimation on the persistence of volatility shocks shows that only Indonesia, Thailand, Singapore and Korea were able to show the persistence of volatility shocks in exchange rate return. This is important in explaining the volatility impact in exchange rate return for the countries mentioned onto Malaysia's market and at the same time to reflect the contagion effect onto the Malaysian financial market. The GJR GARCH $(1,1)$ estimation model in Table 4 has taken into account the asymmetric shock impact towards volatility in exchange rate return.

The positive shock impact in the above model is shown by the value $\alpha_{1}$, while the negative shock impact is described by the sum of $\alpha_{1}$ and $\gamma$. This model tries to see whether there is more influence through positive shock or negative shock in exchange rate volatility. This is called the leverage effect which is normally linked to the declining market activity.

From Table 4, estimation towards the exchange rate return provides more explanations on the existence of the leverage effect caused by the negative shock. The result is consistent and significantly with the case of Indonesia, Thailand, Korea and Singapore compared to Malaysia and Philippines. On the other hand, there is no significant positive shock impact occurred for all countries. This result would be vital to explain the contagion crisis theory onto the Malaysia's financial market which originated from the countries mentioned such as those shown in Table 4. The outcomes also propose that the contagion crisis impact onto the Malaysian financial market is due more to the negative shock impact on the financial market than the positive shock.

Table 5 explains about the modeling of the contagion volatility which spread through the Malaysian currency market by using the GARCH $(1,1)$ model which is modified in order to take into account the external shock impact onto the Malaysian financial market especially in the exchange rate market.

Conditional volatility on the Malaysian Ringgit was caused by the shock impact to the Thai Baht and the Singapore Dollar. However, the volatility impact of the Singapore Dollar was found to be greater than the Thailand Baht. This finding more or less supports the argument and theory that viewed the financial crisis that struck Malaysia was caused by the contagion effect especially from the neighboring countries particularly from Thailand and Singapore, and the indirect effect from Korea and other countries. There may be truth behind the contagion theory to explain this phenomenon and to further conclude, the crisis that struck the countries was not merely due to their weak basic economic fundamentals. The weaknesses in the economic structures only act as the catalyst to the occurrence of the crisis.

\section{Conclusion}

Since the occurrence of the Asian financial crisis in the mid-1997, the contagion theory and the crisis have frequently been debated among economists. Various opinions have been presented and proposed on these issues. In such case, Malaysia is also not exempted from being a study sample and at the same time, attracting many researchers' attention. Aside from the fact that Malaysia recovered quickly from this crisis, what has become more appealing is that whether the crisis which struck Malaysia was merely due to the weakness in the basic economic fundamentals or caused by other factors such as the contagion effect from the neighboring countries. 
Previous studies also concluded that the crisis which happened in Malaysia was caused by the contagion effect which started in Thailand and Korea. However, there are also empirical results showing that the contagion effect was not only come from Thailand and Korea, but also from Singapore and Indonesia, whether directly or indirectly. These views also agree that the financial market was the most effective channel in spreading the contagion.

However, there are also views from several researchers who concluded from the results of their empirical tests that the contagion did not exist to be the cause of the spread of the crisis to the whole Asian region and several other countries in the world. Rigobon (1999) for example, suggested that in reality, the crisis that happened in the Asian region was not caused by the contagion effect but was more due to the presence of certain characteristics which created the concept of the contagion. According to him, the economic systems of most countries in this region have the same foundation or characteristics. This means that the crisis that happened in the one country is simultaneously followed by the crisis in other countries. However, this phenomenon was purely coincidental and was not caused by the contagion effect. In another case, contagion may be more obvious during the time of a crisis, though the contagion could still exist in when no crisis presents.

The differences in opinions mentioned above would become more obscure if the definition of infection or contagion is based on certain classification such as the one proposed by Rigobon because it cannot be determined specifically. However, if the definition of infection or contagion is straightforward and agreeable to most researchers which is about the collapse in one country and creates speculative attacks onto other countries, as a transmission of volatility occurring between one country and another country, and as a change in the spread of shock among affected countries, ceteris paribus, without a more complex definition for contagion, then contagion analysis will become easier.

The empirical result of this study supports the initial view that effects of the contagion crisis from the neighboring countries especially from Thailand and Singapore, did exist in Malaysia. The findings of this study also suggest that the financial sector played a very effective role in spreading the crisis from one country to another. Likewise for Malaysia, this sector became the channel in spreading the crisis to this country. The complex network links in the global financial system would spread the impact of the collapse of a country's economy to another at such a high speed through the financial transmission channel.

From the beginning of the crisis in the mid-1997, the regional economy of the Asian countries including the economy of Malaysia became weaker due to the business networks and the interdependency in many ways. The various efforts were made but not sufficient to restore the economies of the region in a short period of time. This situation was aggravated even more by the assistance by IMF which did not help to restore Asia's economy, but instead worsen the economic situation.

Apart from these, the spread of the crisis among countries in the region is also linked directly to the contagion effect which started in Thailand. Yet, it cannot be denied that the indirect contagion effects from other nations such as Singapore and others country were also parts of the spread of the crisis. Although the crisis reputedly stemmed from the weak basic economic fundamentals of the countries involved, yet this does not mean that contagion is not linked in anyway to the phenomenon. The countries' structural economic weakness was the catalyst to further accelerate the spread of the crisis all over the region and also onto some other countries in the world.

The financial crisis of which in its early stage started in Thailand probably would not have spread over so rapidly if the country had floated its currency earlier. If Thailand did float its currency earlier, then its reserves could have been used to restore the economic status for example, to repay its national debt of which was in large amount. This action could have help to resist the outbreak in other countries.

\section{References}

Akgiray, V. (1989). Conditional heteroskedasticity in time series of stock returns: evidence and forecasts. Journal of Business, 62: 57-80.

Baig, T. and Goldfajn, I. (1999). Financial market contagion in the Asian crisis. IMF Staff Paper, 46(2): 167-195.

Bollerslev, T. (1986). Generalized autoregressive conditional heteroskedasticity. Journal of Econometrics, 31: 307-327.

Dungey, M. and Martin, V. L. (2000). Measuring contagion in the East Asian currency crisis. [Online] Available: http://economics.anu.edu.au/staff/dungey/pdfs/contag5.pdf.

Engle, R. F. (1982). Autoregressive conditional heteroskedasticity with estimates of the variance of U.K. inflation. Econometrica, 50: 987-1008.

Engle, R. F. (1993). Technical note: statistical models for financial volatility. Financial Analysts Journal, January-February: 72-78. 
Frankel, J. A. and Schmukler, S. L. (1998). Crisis, contagion, and country funds: effects on East Asia and Latin America. [Online] Available: http://wwwl.worldbank.org/economic policy/managing\%20 volatility/contagion/documents/FrankSchm.pdf.

Glosten, L. R., Jagannathan, R. \& Runkle, D. E. (1993). On the relation between the expected value and the volatility of the nominal excess return on stocks. The Journal of Finance, 48: 1779-1802.

Hill, R.C., Griffiths, W.E. and Lim, G.C. (2008). Principles of econometrics, $3^{\text {rd }}$ Ed. Massachusetts: John Wiley \& Sons, Inc.

IMF. (1980). International Financial Statistics Yearbook.

IMF. (1990). International Financial Statistics Yearbook.

IMF. (2001). International Financial Statistics Yearbook.

IMF. International Financial Statistics, Monthly.

Ishak Shari. (2000). Krisis kewangan dan ekonomi 1997-98 di Malaysia: apakah yang dapat dipelajari? Pnyt. Noraini Othman \& Sumit K. Mandal, dalam Malaysia menangani globalisasi: peserta atau mangsa? Bangi: Penerbit UKM.

Kaminsky, G. L. and Reinhart, C. M. (1998). On crises, contagion, and confusion. [Online] Available: http://www1.worldbank.org/economicpolicy/managing\%20volatility/contagion/documents/cont.pdf.

Kawai, M., Newfarmer, R. and Schmukler, S. (2001). Crisis and contagion in East Asia: nine lessons. [Online] Available: http://www.wordbank.org/research/pdffiles/Kawai-Newfarmer-Schmukler-WBRO. pdf

Koutmos, G. and Saidi, R. (2001). Positif feedback trading in emerging capital markets. Applied Financial Economics, 11: 291-297.

Md. Nasrudin Hj. Md. Akhir. (2000). Jepun dan krisis kewangan Asia Tenggara (ASEAN). Pemikir, Julai-September: 81-101.

Rigobon, R. (1999). Does contagion exists? [Online] Available: http://web.mit.edu/rigobon/www/Pdfs /DoesContagionExists.pdf.

Ugarteche, O. (2000). The false dilemma globalization: opportunity or threat? Terj: Mark Fried. New York: Zed Books Ltd.

Wee Beng, G., Lee Ying, S. and Chee Chee, S. (1999). The Ringgit and the Malaysian financial crisis: an interpretation. Malaysian Journal of Economic Studies, XXXVI(1): 45-74.

Wong Peng Yie. (2000). Realiti dalam pertaruhan. Business \& Industry, 56: 70-71.

Zakoian, J.M. (1994). Threshold heteroskedastic models. Journal of Economic Dynamics and Control, 18: 931-944.

Table 1. Summary Statistics

\begin{tabular}{ccccccccc}
\hline & Mean & Median & Max & Min & STD & Skewness & Kurtosis & JB \\
\cline { 2 - 9 } & \multicolumn{7}{c}{ Exchange Rate (ER) } \\
\hline Malaysia & 3.76 & 3.80 & 4.57 & 2.64 & 0.32 & -1.22 & 7.35 & $39.39^{*}$ \\
Indonesia & 7833.34 & 7985.00 & 14900.00 & 2599.00 & 2532.38 & 0.10 & 3.99 & 1.62 \\
Philippines & 39.55 & 40.07 & 45.08 & 28.97 & 3.49 & -1.16 & 4.75 & $13.39^{*}$ \\
Thailand & 39.12 & 38.54 & 54.92 & 32.07 & 3.69 & 2.20 & 10.58 & $121.67^{*}$ \\
Singapore & 1.67 & 1.69 & 1.78 & 1.47 & 0.07 & -1.20 & 4.07 & $11.00^{*}$ \\
Korea & 1213.37 & 1186.00 & 1695.00 & 892.00 & 173.51 & 0.68 & 4.02 & 4.54 \\
\hline
\end{tabular}

Notes: * ,** denote significant at the $1 \%$ and $10 \%$ levels respectively. STD $=$ Standard Deviation, Max $=$ Maximum, Min $=$ Minimum dan JB $=$ Jarque-Bera Statistic. 
Table 2. Correlation Analysis

\begin{tabular}{ccccccc}
\hline & Malaysia & Indonesia & Thailand & Singapore & Korea & Philippines \\
\cline { 2 - 6 } & & \multicolumn{3}{c}{ Exchange Rate (ER) } \\
\hline Malaysia & 1.000 & - & - & - & - & - \\
Indonesia & $0.787^{*}$ & 1.000 & - & - & - & - \\
Thailand & $0.667^{*}$ & $0.388^{* *}$ & 1.000 & - & - & - \\
Singapore & $0.845^{*}$ & $0.704^{*}$ & $0.420^{*}$ & 1.000 & - & - \\
Korea & $0.622^{*}$ & $0.488^{*}$ & $0.676^{*}$ & $0.316^{* * *}$ & 1.000 & $0.447^{*}$ \\
Philippines & $0.809^{*}$ & $0.730^{*}$ & $0.493^{*}$ & $0.813^{*}$ & 000 \\
\hline
\end{tabular}

Note: $* * *, * * *$ denote significant at the $1 \%, 5 \%$ and $10 \%$ levels respectively.

Table 3. GARCH $(1,1)$ Estimation

\begin{tabular}{|c|c|c|c|c|c|c|}
\hline & Malaysia & Indonesia & Philippines & Thailand & Singapore & Korea \\
\hline \multicolumn{7}{|c|}{ Equation (i) \& (ii): Exchange Rate Return (S) } \\
\hline$\rho_{0}$ & $\begin{array}{l}-0.0007 \\
(0.0008)\end{array}$ & $\begin{array}{l}0.0007 \\
(0.025)\end{array}$ & $\begin{array}{c}0.006 \\
(0.004)\end{array}$ & $\begin{array}{c}0.002 \\
(0.004)\end{array}$ & $\begin{array}{c}0.002 \\
(0.003)\end{array}$ & $\begin{array}{l}-0.005 \\
(0.004)\end{array}$ \\
\hline$\rho_{1}$ & $\begin{array}{c}0.086 \\
(0.144)\end{array}$ & $\begin{array}{l}-0.080 \\
(0.175)\end{array}$ & $\begin{array}{c}0.027 \\
(0.117)\end{array}$ & $\begin{array}{l}-0.034 \\
(0.211)\end{array}$ & $\begin{array}{l}-0.241 \\
(0.188)\end{array}$ & $\begin{array}{c}0.191 \\
(0.173)\end{array}$ \\
\hline$\alpha_{0}$ & $\begin{array}{c}6.58 \mathrm{E}-05 \\
(4.75 \mathrm{E}-05)\end{array}$ & $\begin{array}{c}0.0006 \\
(0.0005)\end{array}$ & $\begin{array}{c}6.56 \mathrm{E}-06 \\
(3.55 \mathrm{E}-05)\end{array}$ & $\begin{array}{c}0.0003 \\
(0.0002)\end{array}$ & $\begin{array}{c}3.39 \mathrm{E}-06 \\
(9.32 \mathrm{E}-06)\end{array}$ & $\begin{array}{c}2.55 \mathrm{E}-05 \\
(3.31 \mathrm{E}-05)\end{array}$ \\
\hline$\alpha_{1}$ & $\begin{array}{c}0.716^{* * * *} \\
(0.403)\end{array}$ & $\begin{array}{l}0.054 * \\
(0.020)\end{array}$ & $\begin{array}{c}0.082 \\
(0.149)\end{array}$ & $\begin{array}{c}0.577 * * \\
(0.279)\end{array}$ & $\begin{array}{c}0.186 \\
(0.135)\end{array}$ & $\begin{array}{l}0.051 * \\
(0.010)\end{array}$ \\
\hline$\beta_{1}$ & $\begin{array}{c}0.359 * * \\
(0.178)\end{array}$ & $\begin{array}{l}0.939 * \\
(0.017)\end{array}$ & $\begin{array}{l}0.998 * \\
(0.229)\end{array}$ & $\begin{array}{c}0.404 * * * \\
(0.227)\end{array}$ & $\begin{array}{l}0.754^{*} \\
(0.111)\end{array}$ & $\begin{array}{l}0.946^{*} \\
(0.004)\end{array}$ \\
\hline$\alpha_{1}+\beta_{1}$ & 1.075 & 0.993 & 1.080 & 0.981 & 0.940 & 0.997 \\
\hline
\end{tabular}

Notes: $*, * *, * * *$ denote significant at the $1 \%, 5 \%$ and $10 \% . \mathrm{y}=\mathrm{S}$ and $\mathrm{D}=$ dummy where 1 if financial crisis begin in July 1997 and 0 others. The total parameter of $\alpha_{1}+\beta_{1} \leq 1$ shows the persistence of volatility shocks in the exchange rate return. Number in parentheses are standard error.

Table 4. GJR-GARCH $(1,1)$ Estimation

$$
y_{t}=\rho_{0}+\rho_{1} y_{t-1}+\varepsilon_{t} \quad \varepsilon_{t} \mid \psi_{t} \sim N\left(0, h_{t}\right) \quad h_{t}=\alpha_{0}+\alpha_{1} \varepsilon_{t-1}^{2}+\beta_{1} h_{t-1}+\gamma D_{t-1}^{-} \varepsilon_{t-1}^{2}
$$

\begin{tabular}{|c|c|c|c|c|c|c|}
\hline & Malaysia & Indonesia & Philippines & Thailand & Singapore & Korea \\
\hline \multicolumn{7}{|c|}{ Exchange Rate Return (S) } \\
\hline \multirow[t]{2}{*}{$\rho_{0}$} & -0.050 & -0.029 & 0.288 & 0.441 & 0.242 & $-1.095 * *$ \\
\hline & $(0.073)$ & $(3.604)$ & $(0.378)$ & $(0.997)$ & $(0.180)$ & $(0.491)$ \\
\hline \multirow{2}{*}{$\rho_{1}$} & -0.058 & -0.035 & 0.132 & 0.038 & -0.087 & 0.125 \\
\hline & $(0.109)$ & $(0.253)$ & $(0.141)$ & $(0.158)$ & $(0.186)$ & $(0.150)$ \\
\hline \multirow[t]{2}{*}{$\alpha_{0}$} & 0.002 & 6.287 & 1.168 & 3.661 & 0.004 & 1.611 \\
\hline & $(0.019)$ & $(12.340)$ & $(0.830)$ & (4.799) & (1.093) & (1.093) \\
\hline \multirow{2}{*}{$\alpha_{1}$} & 0.559 & 0.003 & 0.285 & 0.142 & 0.111 & 0.134 \\
\hline & $(0.635)$ & $(0.049)$ & $(0.469)$ & $(0.130)$ & $(0.296)$ & $(0.198)$ \\
\hline \multirow[t]{2}{*}{$\beta_{1}$} & 0.006 & $0.820 *$ & $0.818 * *$ & $0.805^{*}$ & $0.990 *$ & $0.832 *$ \\
\hline & $(0.022)$ & $(0.097)$ & $(0.318)$ & $(0.183)$ & $(0.346)$ & $(0.139)$ \\
\hline \multirow[t]{2}{*}{$\gamma$} & -3.939 & $-0.561 * *$ & -0.370 & $-0.773 * * *$ & $-0.500 *$ & $-0.507 * * *$ \\
\hline & (3.993) & $(0.280)$ & $(0.288)$ & $(0.435)$ & $(8.5 \mathrm{E}-102)$ & $(0.269)$ \\
\hline
\end{tabular}

Notes: $* * *, * * *$ denote significant at the $1 \%, 5 \%$ and $10 \%$ levels respectively. $\mathrm{y}=\mathrm{S}$ and number in parentheses are standard error. $D_{t-1}^{-}=1$ if $\varepsilon_{t-1}<0$ and 0 others. 
Table 5. Modelling The Volatility Spillovers Onto Malaysian Financial Market Using GARCH $(1,1)$

$$
\Delta y_{t}=\rho_{0}+\rho_{1} \Delta y_{t-1}+\rho_{2} \Delta y_{t-1}^{q}+\varepsilon_{t} \varepsilon_{t} \mid \psi_{t-1} \sim N\left(0, h_{t}\right) \quad h_{t}=\alpha_{0}+\alpha_{1} \varepsilon_{t-1}^{2}+\beta_{1} h_{t-1}+\gamma_{1} V_{t}^{2 q}+\gamma_{2} V_{t-1}^{2 q}
$$

\begin{tabular}{cccccc}
\hline & Indonesia & Philippines & Thailand & Singapore & Korea \\
\cline { 2 - 5 }$\rho_{0}$ & 0.035 & 0.024 & 0.018 & 0.044 & 0.028 \\
& $(0.159)$ & $(0.044)$ & $(0.045)$ & $(0.042)$ & $(0.112)$ \\
$\rho_{1}$ & 0.110 & 0.125 & 0.303 & 0.130 & -0.078 \\
& $(0.685)$ & $(0.271)$ & $(0.275)$ & $(0.279)$ & $(0.543)$ \\
$\rho_{2}$ & $-4.4 \mathrm{E}-05$ & 0.001 & -0.010 & -0.056 & 0.001 \\
& $(8.6 \mathrm{E}-05)$ & $(0.017)$ & $(0.010)$ & $(0.846)$ & $(0.001)$ \\
$\alpha_{0}$ & 0.031 & 0.002 & 0.013 & 0.010 & 0.023 \\
& $(0.092)$ & $(0.009)$ & $(0.008)$ & $(0.013)$ & $(0.102)$ \\
$\alpha_{1}$ & 0.150 & 0.803 & 0.965 & $0.809^{* *}$ & 0.150 \\
& $(0.349)$ & $(0.496)$ & $(0.620)$ & $(0.379)$ & $(0.669)$ \\
$\beta_{1}$ & 0.600 & 0.018 & 0.048 & 0.011 & 0.600 \\
& $(0.154)$ & $(0.105)$ & $(0.050)$ & $(0.054)$ & $(1.671)$ \\
$\gamma_{1}$ & 0.000 & -0.004 & $-0.008^{* *}$ & $-20.898^{* *}$ & $-2.0 \mathrm{E}-07$ \\
& $(6.5 \mathrm{E}-07)$ & $(0.003)$ & $(0.004)$ & $(10.250)$ & $(3.2 \mathrm{E}-06)$ \\
$\gamma_{2}$ & 0.000 & 0.032 & 0.012 & 37.254 & $4.8 \mathrm{E}-08$ \\
& $(6.4 \mathrm{E}-07)$ & $(0.020)$ & $(0.012)$ & $(29.731)$ & $(4.0 \mathrm{E}-06)$
\end{tabular}

Notes: $* * *, * * *$ denote significant at the $1 \%, 5 \%$ and $10 \%$ levels respectively. $y=S$ for Malaysia and number in parentheses are standard error. $y^{q}=S$ for others countries and $V^{q}=$ varians for others countries $(q=$ others countries except Malaysia). 